\title{
既存住宅ストック活用型の居住水準改善システムの提案と可能性の検討 一東京23区の高齢者所有住宅ストックを対象として一 \\ THE POSSIBILITY OF HOUSING CONDITION IMPROVEMENT SYSTEM THROUGH MANAGEMENT OF EXISTING HOUSING STOCK
}

\author{
石坂公一*，番 水紀行**，近江 隆*** \\ Koichi ISHIZAKA, Noriyuki BANSUI and Takashi OMI
}

\begin{abstract}
This study examined the possibility of improving housing conditions in the twenty-three wards of Tbkyo through practical application of leasing of existing privately owned dwellings occupied by elderly households. The results were as follows: 1. Many elderly households are able to lease the dwellings they own, move into leased dwellings especially designed for the elderly, and obtain income from the cost differential. However, by current market standards of rent, families seeking rental dwellings are unable to live in these because of the high rents.

2. However, by introducing public support into a system that applies such "housing chain," it is possible for the elderly to obtain their income, while at the same time ameliorating housing conditions for family households.

3. If the same funding can be applied as is currently budgeted for improvement of housing conditions, then it can be expected that a system for improvement which utilizes "housing chain" will turn out to be more efficient than the current system.
\end{abstract}

Keywords: housing stock, housing condition, housing management, relocation, housing chains, elderly household

住宅ストック、居住水準、住宅経営、住み替え、住宅連鎖、高齡者世带

1. 研究の背景と目的

近年、社会・経済の成熟化にともない住宅政策は新規建設を中心 としたものから既存ストックの活用を重視する方向へと移行しつつ ある。この中で「既存ストック循環型市場の整備による持続可能な 居住水淮向上システムの構築」「少子・高齢社会に対応した『安心 居住システム』の確立」が今後の政策の基本的方向とされ、「現在 のストック・居住環境を長期的視点から良質なものへと如何にして 再生するか」「ストックの流動化を如何にして実現するか」が当面 の政策課題とされている。このための具体的な方策としては「中古 住宅市場・賃貸住宅市場の活性化」や「ファミリー向け賃貸住宅の 供給」「職住近接のための都心居住の推進」等が挙げられている" がやや抽象的であるという感は否めない。

本研究では「既存ストック循環型市場の整備による持続可能な居 住水準向上システム」の一案として、高齢者世带が居住している持 家ストックの貸貸借による流動化を通じた「循環型居住水準向上シ ステム」を提案し、それによる借家ファミリー世帯の居住水淮改善 の可能性を経済的な側面から検討する。すなわち「高齡単身・夫婦 のみ世帯が居住する相対的に規模の大きい持家ストック」を「ファ ミリー世帯の居住水準の改善」を実現するための資源としてとらえ、 高齢者世帯にもファミリ一世帯にもメリットのある形でこれを活用
するシステムの可能性を「家貨負担力」という観点から検討する。 持家ストックの流動化を促進するための従来の手段は「売買」に着 目した金融・税制的な面からのものが中心であった。しかし、これ らに加えて「賃貸借」に着目したシステムもあり得るのではないか というのが本研究のそもそもの発想である。現在はまだ存在してい ない新たなシステムを提案し、その可能性を検討するという研究方 法は「実態の分析から問題点を把握し政策課題の抽出を行う」とい う通常の研究方法 ${ }^{2)}$ とはやや異質であるが、このような方法を採る ことで、逆に「既存住宅ストックの有効活用」を重視した住宅政策 の展開を図る上での課題を明らかにすることもできるのではないか と考えられる。

\section{2. 本研究で提案する「居住水淮向上システム」}

本研究で提案する「居住水準向上システム」は世帯規模に比べて 住宅規模に相対的に余裕のある持家に居住している高齢の単身・夫 婦のみ世帯に現在所有している住宅を賃貸に出してもらい、新たに 世帯規模に見合い、高齢者用の設備の整った住宅（場合によっては ケア等のサービスが付加された住宅を考えても良い）を賃借して居 住してもらうことを基本としている。もし、高齢者世帯向けの住宅 の家賃が現在所有している住宅を賃貸に出した場合の家賃よりも低
* 東北大学大学院工学研究科都市建築学専攻 助教授 $\cdot$ 工博

** 戸田建設 工修

*** 東北大学大学院工学研究科都市建築学専攻 教授. 工博
Assoc. Prof., Dept. of Architecture, Univ. of Tohoku, Dr. Eng

TODA Construction Ltd., M. Eng.

Prof., Dept. of Architecture, Univ. of Tohoku, Dr. Eng. 
い場合には高齢者世帯は家貨差額に対応する収入を得ることができ る。一方、高齢者世帯が居住していた住宅には住宅規模に対する要 求がより強いファミリー世帯が入居することによりファミリー世帯 の居住水準の改善が図れることになる。従来はこのような流動化は 「売買」を通じて行われることが一般的であった。しかし、高齡者 のなかには当面は高齢者用の設備・サービスが充実した住宅に居住 したいが、将来は自宅を子に相続させたいと考えている世帯や移転 先の状況があまり満足のいくものではない場合には自宅に戻る可能 性を確保しておきたいと考える世帯もあろう。本研究で提案するシ ステムはこのような高龄者世帯の要求にも対応することができるよ うに借地借家法の改正で生まれた定期借家契約を基礎においている。 すなわち、まず公的な主体もしくは信用力のある民間主体が「単身・ 夫婦のみ高齢者世帯向け儥貸住宅」を供給し、高齢者世帯に定期借 家として貸貸する。入居を希望する高齢者世帯は現在の自宅をファ ミリー世帯に貨貸することになるが、この場合、高齢者向け貸貸住 宅の定期借家契約と契約日、契約期間を同一とした定期借家として 貢貸契約を結ぶ。2つの定期借家契約の契約日と契約期間を同一と することで、もし高齢者世帯が自宅に戻りたいと考える場合には契 約期間が満了する日には自宅に戻ることが可能であるし、継続して 居住したい場合には新たに同様の定期借家契約を結ぶことで継続居 住が可能となる。一方、ファミリー世帯の側は契約期間終了時に貸 主である高齢者世帯が契約を継続しない場合には退去せさるを得な いが、高齢者世帯が契約を継続する場合にはまた新たに前回と同様 の形式で定期借家契約を結ぶことで継続して居住することができる。 また、定期借家契約では賃借人が契約期間の途中で契約を解除する こともできるので、ファミリー世帯は転勤等で転居が必要な場合に は途中で契約を解除し退去することも可能である。この場合には高 齡者世帯は別のファミリー世帯と当初の残りの期間を契約期間とす る定期借家契約を結ぶことで当初の予定どおり高齢者向け貸貸住宅 に継続して居住するか、高齢者向け賃貸住宅の契約を途中で解除し 自宅に戻ることになる。

ここでの提案システムの基本形は以上のようであるが、本システ ムが円滑に運用されるためには、次のようないくつかの条件が必要 であると考えられる。

(1)高齢者向け貸貸住宅および貸貸に出される高齢者の所有住宅の家 賃水淮が高齢者世帯にある程度の家賃差額を保証し、かつファミリ 一世帯にとっても支払い可能な水準であること。

(2)高齢者向け貨貸住宅の供給主体は、高齢者世帯との当初の定期借 家契約が満了する時点において高齢者世帯が継続居住を希望する場 合には、原則として契約の更新に応じる主体であること。

(3)同一契約日、契約期間の $2 つ の$ 定期借家契約を同時に締結する必 要があることから、これらの事務や家儥の徵収・支払いを円滑にマ ネージメントできる信頼できる主体が存在すること。

(4)ファミリー世帯が中途解約した場合に次の入居世帯が円滑に確保 できるよう貨借人となるファミリー世帯の一定の需要を常時プール しておく一種の登録制のようなシステムと運営主体が存在すること。 (5)家賃の未収等に起因するトラブルを未然に防止するとともに: ラブルが発生した際にはその解決を行うシステムが存在すること。

提案システムを実施に移す場合には、これ以外にも多くの条件が 必要となるであろうが、システムの実現可能性を検討する上で、も
っとも大きな要因となるのは(1)の家賃水準の条件であると考えられ る。そこで、以下では傢賃負担力の観点から提案システムの可能性 を検討することにしたい。

\section{3. 市場家賃関数の計測}

検討にあたっての対像地域は「都心居住の推進」という観点も考 慮し東京都23区とした。また、23区内でも地域により家賃水準には 差があることから、23区を距離帯、沿線を考慮した表 1 に示す 6 地 区に分けて検討を行うこととした。高齢者世帯・ファミリー世帯に 関するデータソースとしては1998年「住宅・土地統計調査」 ${ }^{3)}$ (以 下、98住調という）を用い、家賃関連のデータはリクルート社「住 宅情報」が公表している個別データを用いた。以下では、専用住宅 の持家に居住する65歳以上の単身世帯と高齢者夫婦世帯を「高齢者 世帯」、3人以上世帯で持家に居住する世帯を「持家ファミリー世 帯」、3人以上世帯で借家に居住する世帯を「借家ファミリー世帯」 と呼ぶことにする。

家賃負担力の観点からシステムの可能性を検討するために、まず 現実の市場における住宅規模、建築時期、最寄り駅までの時間を説 明変数として家貢月額を推計する市場家賃関数を地域別に計測した。 計測にあたっては、ファミリー世帯を対象とするという本研究の趣 旨からワンルームマンションと思われるデータは除外した。具体的 には戸建と共同建の建方 2 区分別にリクルート社「住宅情報」がWeb 上で公表している個別データ ${ }^{4)}$ の $30 \mathrm{~m}^{2}$ 以上の住宅を対象として、こ れに延床面積 $\left(\mathrm{m}^{2}\right)$ 、建築時期（西暦）、最奇り駅までの時間（分） を説明変数、月額の家貢 (万円) を被説明変数とした重回帰分析を 行い、地区 $\times$ 建方別の計12区分について市場家賃関数を算出した。 その際、被説明変数に対する影響力の険定を同時に行い、説明変数 として適切でないと考えられたものは除外した。結果は表 2 に示寸 とおうりであり、決定係数から見ると得られた市場家賃関数は 7〜8 割程度の説明力を有している5)。

\section{4. 提案システムの基本形における可能性の検討}

得られた市場家賃関数と98住調のデータを用いて、地区 $\times$ 建方別 に高龄者世帯が現住居を貨貸した場合に得られる家賃と賃借する高 齢者向け賃貸住宅の家貣から差額収入を求めた。この際、賃借する

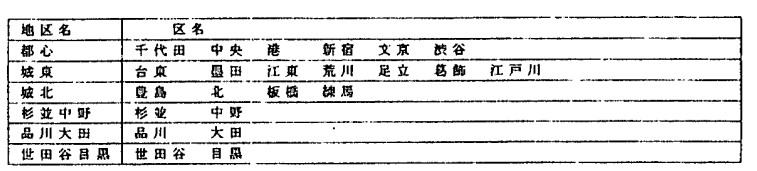

表 1 地域区分

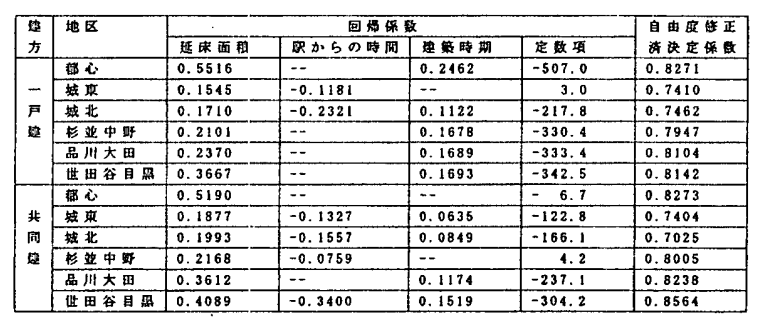

表 2 汸場家貨関数の計測結果 
高齢者向け賃貸住宅は新築の共同建とし、延床面積は都市型誘導居 住水準（単身： $43 \mathrm{~m}^{2} 、 夫$ 夫婦 : $55 \mathrm{~m}^{2}$ ）、駅までの時間は現住居と同一 と仮定した ${ }^{6)}$ 。計算結果は差額収入を 100 万円単位に 9 区分した区 分別に集計し、各区分ごとに高齢者世帯の平均年収、賃貸に出され る住宅の平均延床面積、得られる平均家賃額と世帯数を求めた。各 地区を合計した23区全体についての結果を差額収入区分別に示した ものが図 1 である。円の大きさは世帯数を示し、得られる差額収入 の上昇にともなって平均年収、平均延床面積、平均家傊額が上昇し、 逆に世帯数は減少することがわかる。図は省略するが建築時期、駅 までの時間はどの差額区分でもそれほどの差はなく、1976年前後、 8 分程度が平均的な值である。差額収入が得られる世帯数は 168 千 世帯であり、対象とする高齢者世帯総数 246 千世帯の $68 \%$ を占める。 これから23区内の持家に居住している単身・夫婦のみの高跉者世帯 の約 7 割は差額収入を得つつ高齢者向け賃貸住宅に入居することが 可能であると言える。また、差額収入の額は 0 ～100 万円が約 $50 \%$ で 100〜 200万円を合わせると約77\%となり 200万円未満の世帯が 大半であるが、これらの世帯の平均年収は 400〜 600万円であるこ とから、差額収入は現在の収入の $20 〜 30 \%$ 程度に相当する額となる。 この額が高齢者世帯の移転を促進するインセンティブになり得る額 であるかどうかの評価は難しいが、収入に比べてそれほど小さな額 でないことは確かである。一方、ファミリー世帯向けに賃貸に出さ れる住宅の延床面積は家賃差額が $0 \sim 100$ 万円の場合で $80 \mathrm{~m}^{2} 、 100$ 〜 200万円の場合で 113 年であり、3〜4人のファミリー世帯にと って適切な規模となるが、供給される住宅の家貢は17.6万円／月、 26. 7 万円／月とかなり高額となる。

借家に居住しているファミリー世帯が現実に負担している家貨を 東京都住宅白書 7 で見ると、借家平均で 3 人世帯 84129 円 /月、 4 人世帯 86425 円 /月であり、平均家賃負担率は $19 \%$ である。最も高 い民営借家でも 3 人世帯 105693 円／月、4人世帯 116040 円／月で平 均家賃負担率は $23 \%$ である。この水淮から考えると賃貸住宅として 供給される高齢者所有住宅の家賃はかなり高く、入居可能な借家フ アミリー世帯は限定されると推測される。すなわち、現在の 23 区の 家賃水淮では高齢者世帯側にはかなりの量の潜在的な供給能力があ るが、ファミリー世帯の側にはそれに見合った「需要力」が十分で ないというのが実情である。逆に言えば、現在の家賃水準と借家フ アミリー世帯の負担能力を前提とすると「循環システム」により一 般的なファミリ一世帯に適切な規模の住宅を23区内で大量に供給す ることはかなり困難であると言えよう。

5. 提案システムの抬張と可能性の検討

(1) 提案システムの拡張

前述のように本研究で提案したシステムは基本形のままでは借家 ファミリー世帯の家賃負担能力がネックとなって、一般的な借家フ アミリー世帯の居住水準改善を図ることは困難である。そこでシス テムを一般的な借家ファミリー世帯の負担能力でも入居が可能なよ うに改良することを考える。問題は高齢者世帯から供給される住宅 の家貨と借家ファミリー世帯が支出できる家賃との間の格差にある ので、この格差を分散させるため図 2 に示すようにシステムの基本 形を抎張する。抬張されたシステムの特徵は高齢者世帯と借家ファ ミリー世帯との間に持家ファミリー世帯を介在させることにある。
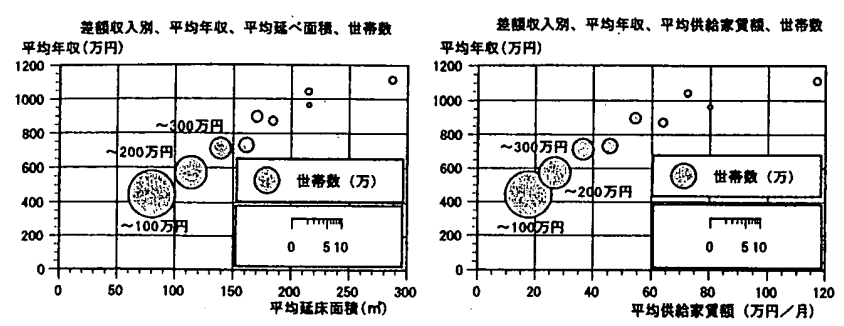

図 $1:$ 差額収入による各指標の变化

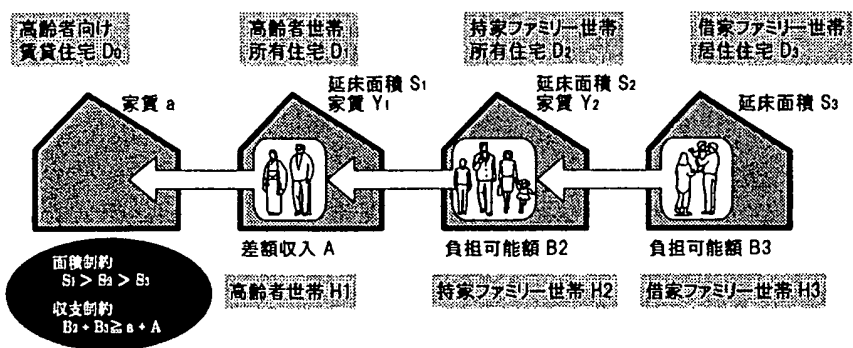

図 $2:$ 住宅連鎖モデル

すなわち、高齢者世帯の持家は一度持家ファミリー世帯によって賃 借され、その後、持家ファミリー世帯の住宅が借家ファミリー世帯 によって賃借されるというものである。住宅連鎖を用いた本システ ムにより、高齢者世带は基本形の場合と同様の差額収入を得ること ができ、持家ファミリー世帯と借家ファミリー世帯は居住水準の改 善を図ることができる。高齢者世帯所有住宅の「高い家賃は持家 ファミリー世帯を連鎖に含めることで、持家・借家ファミリー世帯 で分担して負担される。また、持家ファミリー世帯にとってのメリ ットは最終的な住処としての住宅を所有しつつ、家族構成の変化や 子供の成長による一時的な規模要求の增大に対応できることにある。 一連の連鎖に対して基本形の場合と同様、同一時期に契約が開始・ 終了する定期借家権契約を締結することで、契約期間終了後は連銷 を解消する場合はもとの状態に復帰することも可能であるし、連鎖 を継続する場合はまた新たに同時期に契約が開始・終了する定借家 権契約を締結することで継続的に居住することも可能である。この 場合、自分が賃借している住宅に関しては途中で定期借家契約を解 除することはどの世帯にとっても可能であるが、高路者世帯と持家 ファミリー世帯は当硋世帯が賃貸している住宅の居住者（高齡者世 帯にとっては持家ファミリー世帯、持家ファミリー世帯にとっては 借家ファミリー世帯）が同意しない限り、当初の契約期間中は自宅 には戻れないことになる。ただし、この場合でも契約期間終了後は 自宅に戻ることができるので、定期借家契約の期間をあまり長くな いものとすることで、途中退去にともなう深刻な問題の発生はかな り防げるのではないかと考えられる。

（2）可能性の評価

払張システムによる既存住宅ストックの流動化の可能性を家賃の 面から評価するため、以下のような方法で検討を行った。

(1)分析対象・範囲および記号

供給側となる高齢者世帯については単身・夫婦のみの区分別に地 区6 区分ごとに検討を行う。また、需要側のファミリー世帯は現在 23 区内に居住している 3 人以上の世帯とする。

以下で用いる記号を次のように定める。 
a ：新たに供給される高龄者向け賃貸住宅の家賃

A : 連銷参加によって高齢者世帯が得る家貢収入差額

$S_{1} \quad:$ 高齢者世帯の現住宅の床面積

$\mathrm{Y}_{1}$ ：高齡者世帯によって供給される住宅（現住宅）の家貨

$\mathrm{S}_{2}:$ : 持家ファミリー世帯の現住宅の床面積

$\mathrm{Y}_{2}$ ：持家ファミリー世帯によって供給される住宅（現住宅）家賃

$\mathrm{B}_{2}$ : 持家ファミリ一世帯の追加的家賃負担可能額

$\mathrm{S}_{3}$ : 借家ファミリ一世帯の現住宅の床面積

$\mathrm{B}_{3}$ : 借家ファミリー世帯の家賃負担可能額

(2)住宅連鎖形成の制約条件

検討にあたっては、住宅連鎖が形成可能となる条件として延床面 積制約と家貨負担可能性制約を設けた。

延床面積制約は持家ファミリー世帯、借家ファミリー世帯が現住 居よりも広い住宅つまり居住水準が改善する場合のみ連鎖形成が可 能であるというものであり、 $\mathrm{S}_{1}>\mathrm{S}_{2}>\mathrm{S}_{3}$ で表される。

一方、持家ファミリ一世帯、借家ファミリ一世帯とも連鎖形成に ともなう家賃負担が可能であるためには、

高齢者世帯における定義式 $\quad A=Y_{1}-a \geqq 0$

持家ファミリ一世帯の負担可能制約 $Y_{1}-Y_{2} \leqq B_{2}$

借家ファミリー世帯の負担可能制約 $\mathrm{Y}_{2} \leqq \mathrm{~B}_{3} \quad$ が満たされる必要 があり、このためには $\mathrm{A}+\mathrm{a}-\mathrm{B}_{2} \leqq \mathrm{Y}_{2} \leqq \mathrm{~B}_{3}$ でなければならない。逆に、 $\mathrm{A}+\mathrm{a}-\mathrm{B}_{2} \leqq \mathrm{~B}_{3}$ であれば、このような $\mathrm{Y}_{2}$ が存在し、持家、借家ファミリ 一世帯とも連鎖形成にともなう家賃負担が可能となる。そこで、不 等式 $\mathrm{A}+\mathrm{a} \leqq \mathrm{B}_{2}+\mathrm{B}_{3}$ が成立することを家賃負担可能制約条件と考え ることにする。 $\mathrm{Y}_{1}=\mathrm{A}+\mathrm{a}$ であるので、左辺は家賃水準が低いほど小 さくなる。一方、右辺は家賃水準には関係なく世帯の収入水淮によ って決まる值であるので、収入水準が同一であれば一般的には家貢 水淮が低い場合ほど家賃負担可能制約は満たされやすくなる。

(3)検討方法

可能性の検討は表 3 に示寸区分別に行った。検討にあたり高龄者 世帯についてはシステムの基本形の検討の場合に得られた差額収入 を延床面積18区分について再集計し、差額収入を得られる世帯が存 在寸る15区分 (i区分) を検討の対象とした。持家ファミリー世帯と 借家ファミリー世帯については延床面積18区分（j区分）と収入 9 区 分 (k区分) のクロス集計表を基礶的なデータとした。

高齢者向け貸貸住宅の家貨の設定は先に求めた市場家賃関数から 延床面積を誘導居住水淮（単身： $43 \mathrm{~m}^{2}$ 、夫婦のみ: $55 \mathrm{~m}^{2}$ ）とし、建 筑時期は調査時の新筑（1998年）、駅までの時間は 5 分としたもの を用いた。また、持家ファミリ一世帯の追加的家賃負担可能額は、 既に現在の持家を取得する際にローンを負担していると想定される ことから、年収の $5 \%$ 、借家ファミリー世帯の家賃負担可能額は年 収の $15 \%$ と設定した。この設定值は前述した東京都の平均負担率よ りはやや低いが現実の家賃負担率は「適正」な水準よりはやや高い と考えられること、およびシステムの可能性をよりきびしくチェッ クすることを意図したためである。

可能性の検討結果の評価は以下の指標により求めた借家カバー率

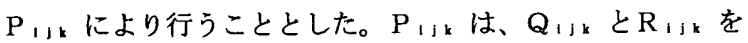

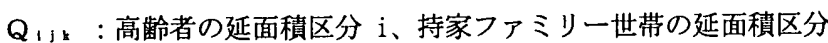
$\mathrm{j}$ 、持家ファミリー世帯の年収区分 $\mathrm{k}$ のときに、面積制約、 家賃負担可能制約の両制約条件を満たした最大成約可能戸数
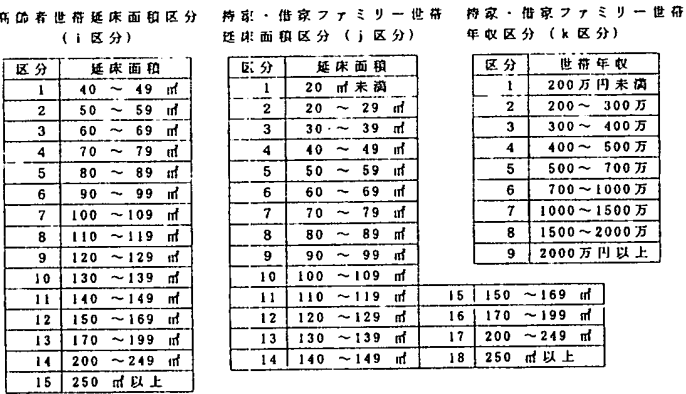

婊 3 各指標区分
（高齢者世帯数と持家ファミリー世帯数のどちらか小さい方）

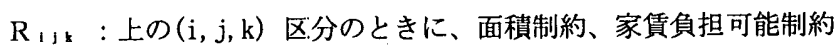
の両制約条件を満たした借家ファミリー世帯総数

としたとき、

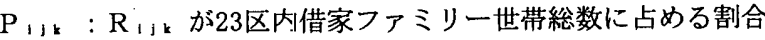

として定義される。

すなわちQ， k は $(\mathrm{i}, \mathrm{j}, \mathrm{k})$ 区分における条件を満足する形成可能 な住宅連鎖数であり、 $P_{1, k}$ は当該連鎖によって供給される住宅へ の借家ファミリー世帯の入居可能ポテンシャルを表す指標となる。 23 区内の借家ファミリー世帯の総数は約 36 万世帯であるので、借家 カバー率の $1 \%$ は約3600世帯に相当することになる。

計算結果は地区X高歯者世帯の世帯型の計12区分別に各 $i, j, k$ の 3 次元表として得られるがそのままではあまりに煩雑となるので、 検討にあたっては借家かバー率 $\mathrm{P}_{11 k}$ を最大成約可能戸数 $\mathrm{Q}_{1 j k}$ で 加重平均して 2 次元化した以下の指標を用いることとした。

$$
\begin{aligned}
& P_{1 j}=\Sigma_{k} P_{1 j k}\left(Q_{1, k} / Q_{11}\right) \cdots(1) \\
& P_{1, k}=\Sigma_{j} P_{1 ; k}\left(Q_{1 j k} / Q_{1, k}\right) \cdots(2) \\
& \text { ただし } Q_{1 j} .=\Sigma_{k} Q_{1 ; k} 、 Q_{1, k}=\Sigma_{1} Q_{11 k} \text { である。 }
\end{aligned}
$$

(1)は高齢者世帯所有住宅と持家ファミリー世帯居住住宅の延床面積 区分に着目したもので、供給される住宅規模別の借家ファミリー世 帯の平均的な入居可能ポテンシャルを表している。(2)は高齢者世帯 の延床面積区分と持家ファミリー世帯の収入区分に着目したもので、 連鎖を形成する持家ファ゚ミリー世帯の収入区分別の平均的な入居可 能ポテンシャルを表している。これら二つの指標を合わせて見るこ とで持家ファミリー世率がどのような世帯の場合に借家ファミリー 世帯の入居可能ポテンジルが高くなるかを把握することができる。 (4)市場家賃水淮のもとでの検討結果

はじめに基本的なケーースとして、家賃水準に対して何らの公的な 関与も行わず、現実の污場家賃そのままの水淮とした場合について 見てみる。すなわち、高齢者向け賃貸住宅家賃および高齡者所有住 宅の賃貸化家賃を市場筷賃関数によって決定した場合である。地区 ×高齢者世帯の世帯型の計12区分別の結果のうち特徽的な都心・単 身と城東・単身についた見ると、都心・単身の場合、借家カバー率 P、は最大でも $0.7 \%$ 程度となる。借家カバー率が $0.5 \%$ あっ ても対象となる借家ファミリー世帯数は約1800世帯であるので連鎖 形成の可能性は 0 ではないが、一般的には都心地区のような家賃が 高い地域では中間に持家ファミリー世帯を介在させたとしても高齢 者世帯によって供給される住宅の家賃を負担できる借家ファミリー 世帯の割合はかなり限引れていると言える。城東・単身では、やや 状況は改善し、高齢者圮帯の所有住宅70〜 $79 \mathrm{~m}^{2}$ と持家ファミリー世 
带の所有住宅60～69 $\mathrm{m}^{2}$ を組み合わせたとき $\mathrm{P}_{1}$, ， は最大值 $11 \%$ をと り、全体としては図 3左のような分布となる。また、城東・単身の $\mathrm{P}_{1}$ ， k を見ると、図 3 右のような分布となる。持家ファミリー世帯 の年収が高くなるほど家賃負担可能制約は満たされやすくなるので、 持家ファミリ一世帯の高収入区分で $\mathrm{P}$. $\mathrm{k}$ が高くなるのは当然であ るが、持家ファミリー世帯のうち高収入区分に属寸る世帯は自力で も居住状況の改善が可能であると考えられるにもかかわらず、敢え て現住宅に居住している世帯であり、連鎖への参加インセンティブ は乏しいと思われる。むしろ、高齢者世帯所有住宅が 80 〜 $89 \mathrm{~m}^{2}$ の時 に借家カバー率が $2.5 \%$ 以上となる範囲が持家ファミリー世帯の年 収 300〜 400万円の層まで広がっていることに注目すべきであろう。 $2.5 \%$ は約 9000 世帯に相当するので、城東・単身の場合には連鎖形 成の際の高歯者所有住宅の規模を適切に選ぶことで市場家顀を前提 とした場合でも連鎖形成の可能性は都心 ・単身の場合よりもかなり 高いと言える。ただ、借家カバー率 $5 \%$ (18000世帯) を連鎖成立の 可能性のひとつの目安とすると、市場家賃の前提のもとでは連鎖成 立の可能性を持つ世带の割合はそれほど多くはない。他の地区およ び高齢夫婦のみ世帯を対象とした場合でも傾向はほぼ同様であり、 家賃水準の高い都心、世田谷目黒、杉並中野では借家カバー率の值 は低く、家貨水淮が低い地区になるにつれて值は上昇するものの絶 対値はそれほど大きくはならない。このことは市場における家賃水 淮を前提とした場合には、持家ファミリー世帯を介在させたシステ ムにおいても「職住近接のための都心居住の推進」「既存ストック 循環型市場の整備による持続可能な居住水淮向上システムの構筑」 「ファミリー向け賃貸住宅の供給」という課題を実現することはそ う簡単ではないことを意味している。

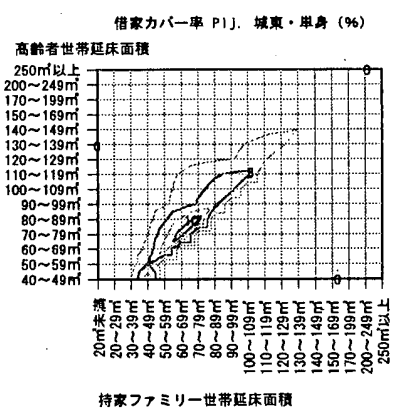

図 3 : 市場でのシミュレーション

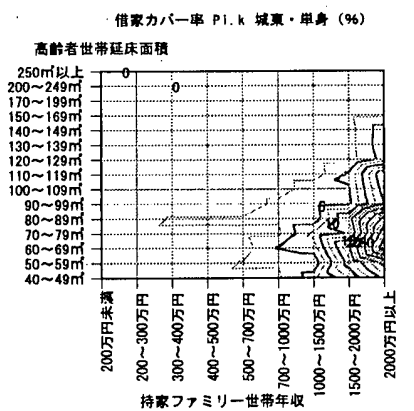

(城東・単身)

\section{6. システムへの公的援助の導入}

それでは連銷形成の可能性を增加させるためにはどのような手段 を講じることが必要なのであろうか。基本的には現実の市場家貨の 水淮が借家ファミリー世帯の家賃負担能力に比べて高額に過ぎ、中 間に持家ファミリー世帯を介在させても、家賃負担可能制約条件 $\mathrm{A}+\mathrm{a} \leqq \mathrm{B}_{2}+\mathrm{B}_{3}$ が成り立ちにくいことが原因となっているのであるか ら、何らかの手段により左辺を減少させるか右辺を增加させる必要 がある。この際、高齢者世帯の得る差額収入Aを減少させることは 高齢者世帯の高齢者向け賃貸住宅への移連インセンティブを減少さ せてしまうし、持家ファミリー世帯の追加的家貨支出 $\mathrm{B}_{2}$ を增加さ せることは持家ファミリー世帯の連鎖参加へのインセンティブに墨 影響を及ぼしてしまう。また、借家ファミリー世帯の家賃負担額 $\mathrm{B}$ を增加させることは一般的な借家ファミリ一世帯の居住水淮を改善
するというシステムの目的自体に反してしまうことになる。このた め、家賃負担可能制約条件を成り立ちやすくするために住宅対策費 として公的援助を導入することを考える。公的援助額を $\mathrm{p}$ とすると $\mathrm{p}$ の投入方法には大きく分けて 2 つあるひとつは左辺をA+a-p と するものであり、高㱓者世帯の差額収入を保証するか、高齢者世帯 向け賃貸住宅の家賃を低減することに投入するもので供給側への投 入となる。もうひとつは右辺を $\mathrm{B}_{2}+\mathrm{B}_{3}+\mathrm{p}$ とするもので持家ファミリ 一世帯や借家ファミリー世帯への家賃補助に相当する需要側への投 入となる。ここでは「既存住宅ストックの有効活用」という観点か ら、供給側となる高齡者世帯に直接的な影響を持つと考えられる左 辺一公的援助を投入した場合について検討してみることにする。

まず、基本的な考え方として「既存住宅ストックの有効活用」の 原資となる高齢者世帯から供給される住宅の供給量を確保するため、 高齢者世帯には市場家貨の水淮で高齢者向け貸貸住宅に入居し、自 宅を貸貸に出した場合に得られる差額収入Aを定額として保証する ことにする。その上で、新たに供給する高齢者向け賃貸住宅に公的 な援助を導入し、市場で評価した場合の家賃 a をより低額な家任a” とし、高齡者世帯にはa'で貸貸する。このままでは高龄者向け賃貸 住宅の家賃低減分 a-a' は差額収入として高齢者世帯に帰属してし まい、借家ファミリー世帯の家賃低減には寄与しないので、高齢者 世帯には自宅を賃貸に出す場合の家賃を $Y_{i}{ }^{\prime}=a^{\prime}+A<a+A=Y$, として a-a'だけ低い家貨で持家ファミリ一世帯に賃貸してもらう。持家 ファミリー世帯の追加的家賃負担額は市場家賃の場合と同額と寸る と、高齢者向け賃貸住宅の家賃の低減分は借家ファミリー世帯向け の家賃低減分として実現され、借家ファミリー世帯向けの家貨は、 市場家顀の場合における $\mathrm{Y}_{2}$ から $\mathrm{Y}_{2}{ }^{\prime}=\mathrm{Y}_{2}-\left(\mathrm{a}-\mathrm{a}^{\prime}\right)$ に低减されることに なる。これは公的援助を高㱓者向け賃貸住宅の家賃低減に投入した 場合であるが、高秢者に定額保証する差額収入 $\mathrm{A} に A=A^{\prime}+B$ となるよ うに公的援助 $B$ を導入し、高齢者世帯が貸し出す住宅の家賃を $\mathrm{Y}_{1}{ }^{\prime}=\mathrm{a}+\mathrm{A}^{\prime}<\mathrm{a}+\mathrm{A}=\mathrm{Y}_{1}$ とすること、および両者を併用して $\mathrm{Y}_{1}{ }^{\prime \prime}=\mathrm{a}^{\prime}+\mathrm{A}^{\prime}$ とすることでも最終的に借家ファミリー世帯向けの家貨を低減させ ることができる。

以下では、高齢者向け賃貸住宅の家賃割引率を $\mathrm{n} a=\mathrm{a}^{\prime} / \mathrm{a}$ 、差額 保証率を $\mathrm{n}_{\mathrm{A}}=\mathrm{B} / \mathrm{A}$ とし、 $\mathrm{n}_{\mathrm{a}}$ と $\mathrm{n}_{\mathrm{A}}$ を $\left(n_{\mathrm{a}}, n_{\mathrm{A}}\right)=(0,0) \cdots$ 公的援助無し $\left(n_{a}, n_{A}\right)=(0,0.5) \cdots$ 定額差額収入の $50 \%$ を公的負担 $\left(\mathrm{n}_{\mathrm{a}}, \mathrm{n}_{\mathrm{A}}\right)=(0.5,0) \quad \therefore$ 高齢者向け賃貸住宅家貨を50\%低減 $\left(\mathrm{n}_{\mathrm{a}}, \mathrm{n}_{\mathrm{A}}\right)=(0.5,0.5) \cdots$ 雨者の併用 とした場合について借家ファミリー世帯の入居可能ポテンシャルを 借家カバー率 $\mathrm{P}_{1 \mathrm{j}}$ ，、 $\mathrm{P}_{\mathrm{l}}$ k によって見ていくことにする。公的援 助を考えない場合と同様、地区 $\times$ 世帯型区分のうち、都心・単身と 城東・単身の場合についての $P_{1 \mathrm{j}} 、 、 P_{1, k}$ を図 4〜 7 に示す。 (1) 都心.単身

都心・単身の場合、P、1．の分布は図4のようになり、若干の公 的援助では状況は改善されない。 $\left(n_{a}, n_{A}\right)=(0.5,0.5)$ まで公的援助 を扡大すると、高齢者世帯の供給住宅が $80 \sim 89 \mathrm{~m}^{2}$ 、持家ファミリー 世帯の住宅が70〜 $79 \mathrm{~m}^{2}$ の場合に $\mathrm{P}_{\text {i }}$ ．は最大值 $15.4 \%$ をとり、持家 ファミリー世带の50〜 $89 \mathrm{~m}^{2}$ の住宅と $10 \mathrm{~m}^{2}$ 程度規模の大きい高齢者所 有住宅の組み合わせの場合に借家カバー率は $5 \%$ 以上となる。また、 $\mathrm{P}_{\mathrm{l} . \mathrm{k}}$ は図 5 のようになり、 $\left(\mathrm{n}_{\mathrm{a}}, \mathrm{n}_{\mathrm{A}}\right)=(0.5,0.5)$ においては $\mathrm{P}_{\mathrm{i} . \mathrm{k}}$ 

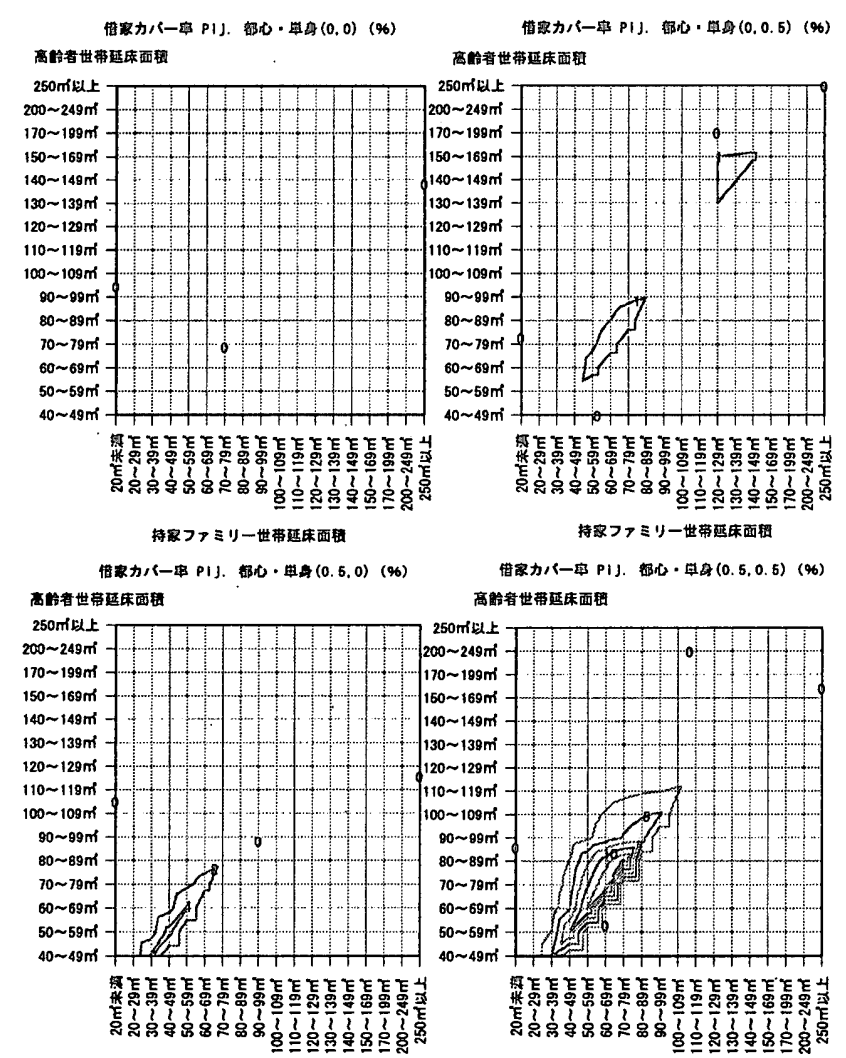

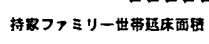

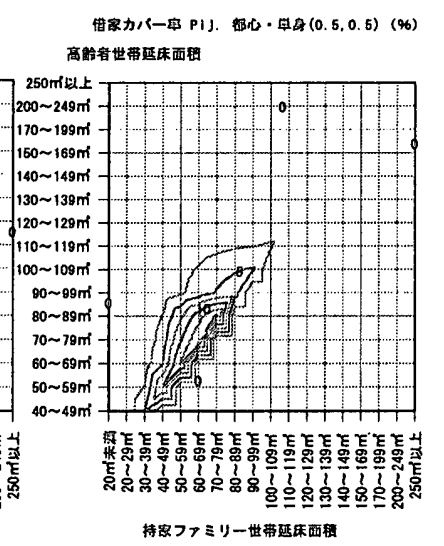

図 4 : 都心・単身 $i \times j$ 区分

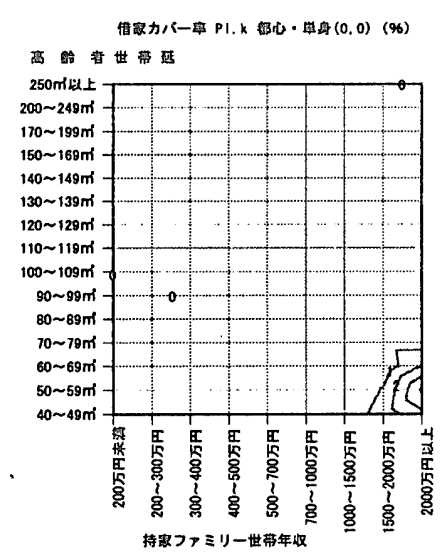

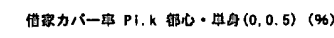

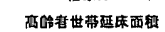

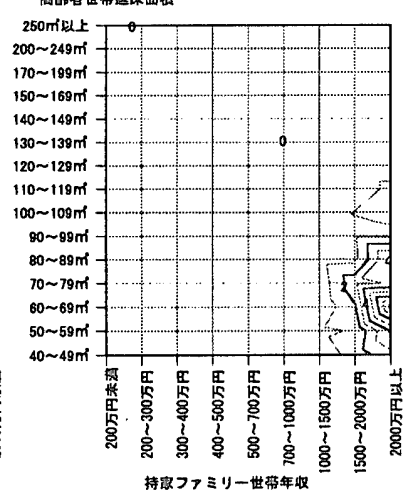

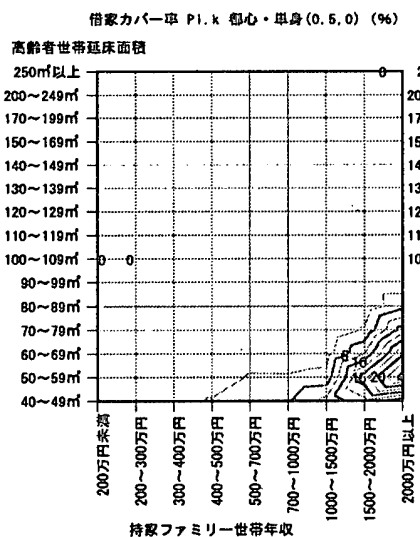

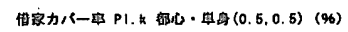

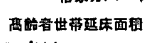

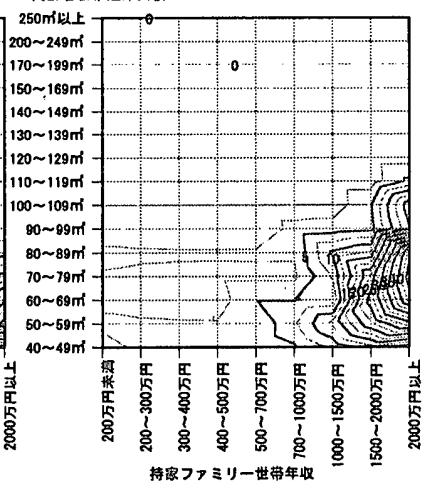

图 5 : 都心・単身 $i \times k$ 区分

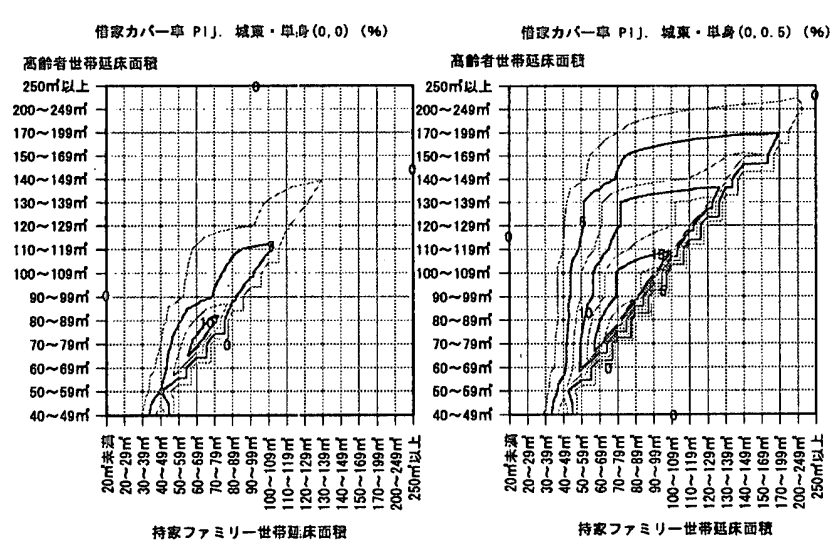

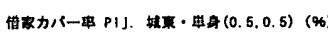

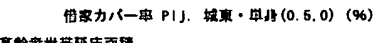

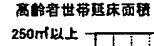

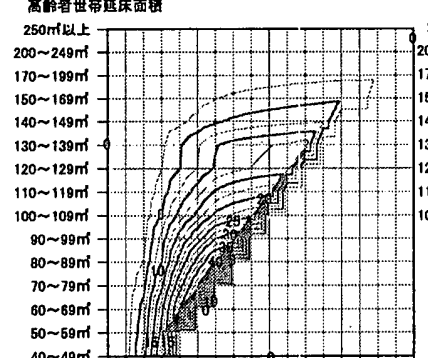

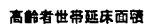
250苚的上

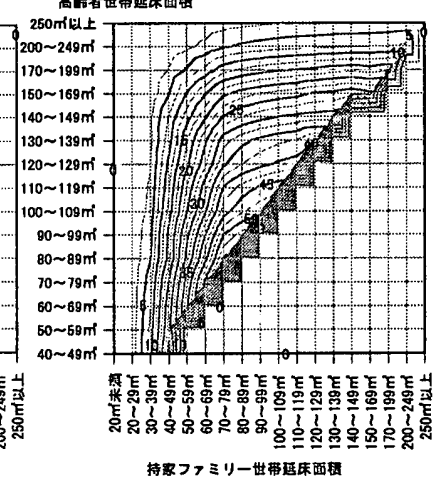

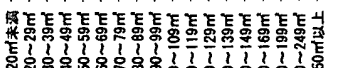

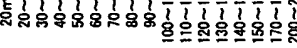

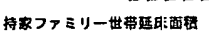

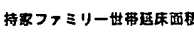

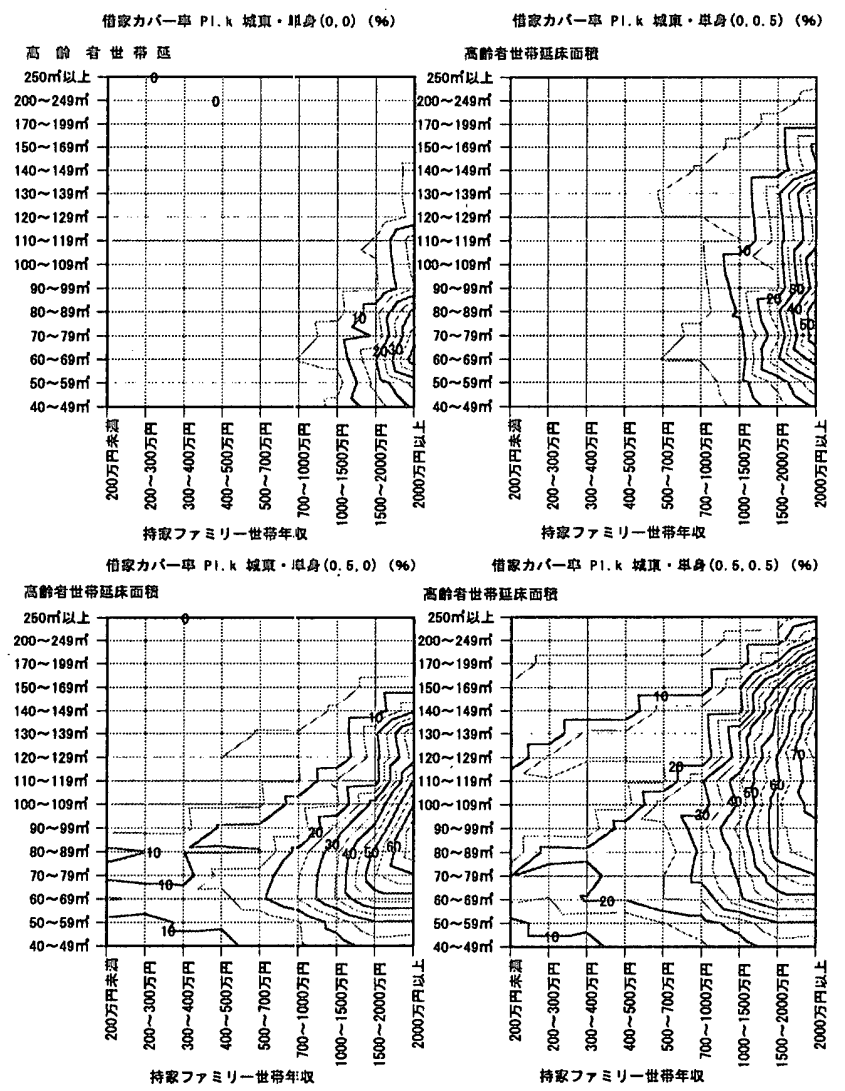

圆 7 : 城東・単身 $i \times k$ 区分 
が $5 \%$ 以上となるのは持家ファミリー世帯の年収がおおむね 800 万 円以上の場合である。都心・単身の場合でも $(0.5,0.5)$ まで公的援 助が挔大されれば住宅連鎖成立の可能性はある程度出てくると言え よう。同様の傾向を示すのはこの他に都心・夫婦、世田谷目黒・単 身、世田谷目黒・夫婦の 3 区分である。

(2) 城東・単身

城東・単身の場合、 $P_{11}$ ．の分布は図 6 のようになる。 $5 \%$ 以上 となる範囲を目安に公的援助の投入による変化を見てゆくと、公的 援助が無い状態から $\left(\mathrm{n}_{\mathrm{a}}, \mathrm{n}_{\mathrm{A}}\right)=(0.5,0.5)$ 人と公的援助を㹡大してい くと、 $\mathrm{P}_{1 \mathrm{j}} .>5 \%$ となる範囲は広动り、高齢者世帯から $45 \mathrm{~m}^{2} \sim 180$ $\mathrm{m}^{2}$ の範囲の住宅の供給が行われることになる。 $\mathrm{P}_{1}$, ，が最大值 $55 \%$ をとるのは高齢者世帯の住宅が $80 \sim 89 \mathrm{~m}^{2}$ 、持家ファミリー世帯の住 宅が70〜 $79 \mathrm{~m}^{2}$ の場合である。一般的に借家入居ポテンシャルは高齢 者住宅が70〜 110 $\mathrm{m}^{2} 、$ 持家ファミリー世帯住宅が50〜 $89 \mathrm{~m}^{2}$ の区分で 高く、ちょうど 3〜 4 人世帯の都市型誘導付近の規模に対応してい る。また、P $\mathrm{i}$ k の分布は図 7 のようになる。定額差額収入一と高 齢者向け貨貸住宅家貨への公的援助を併用した $\left(\mathrm{n}_{\mathrm{a}}, \mathrm{n}_{\mathrm{A}}\right)=(0.5,0.5)$ においては、カバー率の上昇と範囲の拡大が顕著に見られ、高龄者 からの供給住宅が .130〜139 $\mathrm{m}^{2} 、$ 持家ファミリー世帯の年収が 2000 万円以上では $81 \%$ という非常に高い值となる。高齢者向け賃貸住宅 の家賃低減のみに公的援助を行った $\left(\mathrm{n}_{\mathrm{a}}, \mathrm{n}_{\mathrm{A}}\right)=(0.5,0)$ の場合、高歯 者面積区分の上位層では $\mathrm{P}_{1}$. $\mathrm{k}$ はさほど上昇しないが、面積区分が 下位の層では持家ファミリー世帯の相対的低収入層における $\mathrm{P}_{1.4}$ の上眾が顕著である。逆に定額差額仪入に対してのみ公的援助を投 入をした $\left(n_{a}, n_{A}\right)=(0,0.5)$ の場合、高齢者世帯の面積区分の上位層 での值の上昇が顕著であり、面積区分が下位の層における持家ファ ミリー世帯の低収入側での值の変化はあまり見られない。つまり高 齢者向け貨貸住宅の家賃低减側一の公的援助投入は比較的狭い住宅 に住む高齢者世帯からの供給の場合でも家賃負担可能制約が満たさ れやすくなるため、持家ファミリー世帯の相対的に低収入の層で $P_{1}$. . を上昇させる効果がある。一方、高齢者世帯の定額差額側入の投入 は広い住宅に居住する高齡者世帯の高差額収入の場合においても家 賃負担可能制約が満たされやすくなるため、高齢者世帯の面積が上 位の層での $P_{1 . k}$ を上昇させる。すなわち公的援助をどの部分に投 入するかによって、連鎖成立の可能性が向上する世帯型は異なり、 どの層の居住水準向上に重きをおくか柱政策判断の問題となる。

前述したように、城東・単身では公的援助なしでも住宅連鎖は成 立する可能性を持っているが、公的援助が投入された場合には住宅 連鎖成立の可能性が飛躍的に高まり、かつ広い高齢者世帯所有住宅、 広い持家ファミリー世帯所有住宅、低収入層の持家ファミリー世帯 と住宅連鎖が成立する世帯の多様性も高まると言える。

(3) 必要費用面からの検討

以上のように住宅連鎖システムに公的援助を投入することで連鎖 成立の可能性は増加するが、そのための投入必要額はどの程度のも のとなるのであろうか。ここでは、住宅連鎖システムに投入する公 的援助の一連鎖当たりの平均必要費用を都民住宅制度による平均公 的援助額と比較してみることにする。

検討のための指標としては、借家カバー率の総平均 P... を用い る。 $\mathrm{P} \ldots$ は $\mathrm{P}_{\mathrm{i}}$ ，、 $\mathrm{P}_{\mathrm{i} . \mathrm{k}}$ の場合と同様に $(\mathrm{i}, \mathrm{j}, \mathrm{k})$ 区分別の借家 カバー率 $\mathrm{P}_{1, k}$ を最大成約可能戸数 $Q_{1 ; k}$ で加重平均した值として
以下のように定義される。

$\mathrm{P} \ldots=\Sigma_{\mathrm{i}} \Sigma_{1} \Sigma_{\mathrm{k}} \mathrm{P}_{1\} \mathrm{k}}\left(\mathrm{Q}_{1, k} / \mathrm{Q}_{\ldots} \ldots\right) \cdots(3)$

また、一連鎖当たりの平均公的援助額は、同様に $Q_{1\} k}$ で加重平

均した值として、以下で、表される。

$\mathrm{C}=\mathrm{n}, \mathrm{a}+\Sigma, \mathrm{n}_{\wedge} \mathrm{A}_{1}\left(\mathrm{Q}_{1} \ldots / \mathrm{Q} \ldots\right) \quad \cdots(4)$

ただし、Q . = $=\Sigma, \Sigma, \Sigma_{\mathrm{k}} \mathrm{Q}_{1 \mathrm{j} k} 、 \mathrm{Q}_{1} .=\Sigma, \Sigma_{\mathrm{k}} \mathrm{Q}_{1 \mathrm{j} k}$

都民住宅の供給実績は過去10年間で 34721戸、予算額は平成13年 度で約 336億円である。予算額は毎年減額していることから、平均 年3500戸の供給に対して 600 億円程度が投入されてきたことになる。 これは 15 年分の家賃補助額と考えると、戸当たり 9.5 万円／月にあ たる。以下では、都民住宅における公的援助投入額を目安に提案シ ステムへの公的援助必要額を見ていくが、比較にあたり本システム への公的援助は従来型の住宅対策のものとは異なる性格を持つもの であることに注意する必要がある。住宅対策における従来型の公的 援助は基本的には一つの住戸、一つの世帯に対して行われるもので あるが、本システムでは一つの住宅連鎖に対して行われ、高齡者世 帯、持家ファミリー世帯、借家ファミリー世帯と 3 つ異なった世 帯にそれぞれに見合った効果を発揮する。このため公的援助の投入 によってメリットを得られる世帯は 3 世帯に及ぶことになり、住宅 対策としては従来型のものよりもかなり効率的なシステムであると 考えることもできる。

図 8 は横軸に高齢者世帯への差額保証率、䋛軸に高齢者向け賃貸 住宅の家賃割引率をとり、平均借家カバ一率 P . . . を都心・単身と 城東・単身の場合について示したものである。都心・単身の場合、 平均借家カバー率は $\left(\mathrm{n}_{\mathrm{a}}, \mathrm{n}_{\mathrm{A}}\right)=(0.5,0.5)$ とするまで公的援助を拡 大した場合でも $4 \%$ \%゙あり、その際の一連鎖当たりの公的援助額は 19.6万円／月と現在の都民住宅向け家貸補助額の約 2 倍の額となる。 前述したように本システムにおける公的援助投入は 3 世帯に対応す るものなのでこの額はあながち高いとも言えないが、一般的には住 宅連鎖システムの場合でも都心部でのファミリー向け貸貸住宅の供 給にはかなりの財政負担が生じる状況にあると言えよう。

これに対して城東・単身の場合は平均借家カバー率は公的援助の 投入によって大幅に増加する。 $\left(\mathrm{n}_{\mathrm{a}}, \mathrm{n}_{\mathrm{A}}\right)=(0,0)$ では $3 \%$ に過ぎない が、 $\left(\mathrm{n}_{\mathrm{a}}, \mathrm{n}_{\mathrm{A}}\right)=(0.5,0.5)$ となるまで公的援助を抁大すると $23 \% 、 82$ 千世帯をカバーするまでに至る。この際の一連鎖当たりの必要公的 援助額は11.4万円／月であり、都民住宅における投入費用とほぼ同 額となる。公的援助額が都民住宅と同一の 9.5 万円/月の場合には 平均借家カバー率 $19 \%$ となり、借家世帯 67 千.世带が参加可能な住宅 連鎖を形成することができる。概して公的援助投入による平均借家

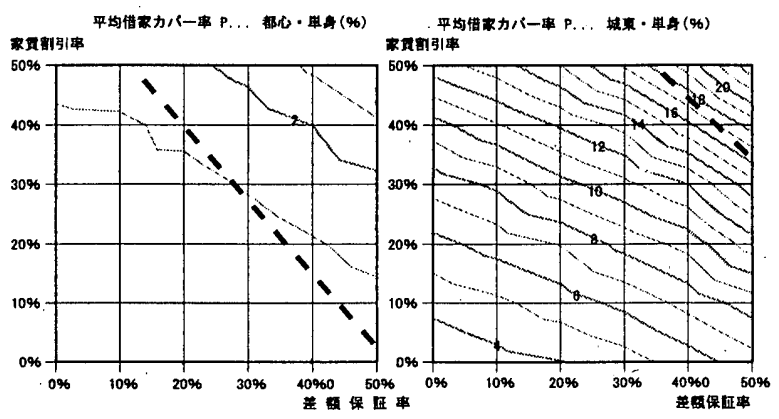

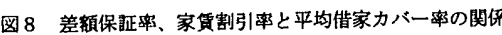
(图中の点線は都民住宅供給に拈け万平均公的援助䫓 9.5 万円 1 月 で可能な水溸を示す） 
カバー率の拡大効果は家賃水淮が相対的に低い地域で顕著である。

\section{7、まとめ}

高齢者世帯所有住宅の賃貸借による流動化を通じたファミリー世 帯の居住水淮向上システムの可能性を検討した本研究の結果をまと めると以下のようになる。

(1)東京23区内の持家に居住する高齢者世帯の多くは自らが居住する 住宅の賃貸借活用により、高跉者向け儥貸住宅への住み替えを行 うことで少なからず収入を得ることができる。しかし、供給され る住宅の家賃は一般的な借家ファミリー世帯の家賃負担能力の水 淮よりもかなり高く、これらの住宅に入居することにより居住水 淮改善が可能な借家ファミリー世帯の割合は限定される。

(2)高龄者世帯から供給される住宅の家賃を低減するために、持家フ アミリー世带を介在させた住宅連鎖システムを考えると家貨水滩 が相対的に低い地域では市場家賃の前提のもとでもある程度の可 能性が出てくるが、持家ファミリー世帯の比較的高収入の層が連 鎖に参加する必要がある。

(3)住宅連鎖システムに対して公的援助を導入することは効果があり、 城東地区等では、現在、都民住宅対策として投入されている程度 の公的援勋額でも連鎖成立の可能性は飛躍的に高まり、一般的な 借家ファミリー世帯に居住水準改善の可能性を提供できる。また、 公的援助の投入にあたって、高齢者向け賃貸住宅の家賃低減にそ れを用いる場合と高齢者世帯の差額収入保証に用いる場合とでは、 連鎖成立が抗大する世帯型は異なるので両者への投入割合を考虑 することで、政策課題に対応した効果を期待することができる。 また、従来型の住宅対策における公的援助の投入と比較すると、 住宅連鎖システムへの公的援助の投入はメリットを受ける世帯が 複数にわたることから、一般的にはより效率的であると考えるこ ともできる。

以上の検討結果からも明らかなように、本研究で提案した「既存 住宅ストックの有効活用による居住水準向上システム」は地域によ っては現在のファミリ一向け賃貸住宅対策と同程度の額の公的援助 の投入によって、一般的な借家ファミリー世帯の居住水準の改善を 図ることが可能である。しかし、本システムによっても都心地域で 一般的なファミリ一世帯に適切な規模の住宅を確保するためには相 当の公的援助の投入が必要である。逆に言えばどんな政策手段をと るにせよ現在の家賃水準のもとでは一般的なファミリ゙ー世帯に「適 切な規模の都心居住住宅」を供給するには相当の政策予算を要する と言えよう。ただ、都心地区においても公的援助がない場合の連鎖 成立の可能性は0ではなく、たとえ $1 \%$ という低い值であっても対 象となる借家ファミリー世帯は約 3500 世帯となるので、高齢者向け 貸貸住宅の供給戸数が 500 戸程度の場合（連鎖形成数が 500 程度の 場合）、潜在的には 7 倍の規模の需要可能世帯が存在することにな る。もちろん、これらの世帯がすべて連鎖形成に参加することを希 望するとは考えられず、需要可能世带数と顕在化する需要との関係 については今後さらに検討する必要がある。また、本研究で提案し た住宅連鎖システムは一般的には家賃水準が低い地域ほど成立可能 性が高まるので、「都心居住」という枠にこだわらなければ、現在 の家賃水淮のもとでもその実現可能性は23区内では最も高い城東地 区よりもさらに高いものになると予想される。今後、本研究で提案
したシステムの可能性をより詳細に検討するためには、23区以外の 地域での検討の他、定期借家権等の法制度面からの検討や住宅政策 における公的援助のあり方、対象となる高齢者世帯・持家ファミリ 一世帯の意向の把握等が必要であると考えられる。

注

1) 21 世紀の豊かな生活を支える住宅・宅地政策について（答申）、平成12年 6 月、住宅宅地審議会

2) 住宅ストックの活用に関連性の深い住居移転や空家を扱った研究は最近のも のに限っても参考文献の1)〜8)に示すように数多いが、ほとんどは実証的な 分析に関わるものである。

3）都市整備公団による特別集計を含む。

4) データの集計は平成13年 9 月に行い、各地区戸建は186 785 サンプルを得 た。また、戸建以外のデータは非常に数が多いため、無作為に各地区500 サ ンプルを抽出して計測を行った。

5)ここで計測した市場家貨関数は定期借家のみを対象としたものではないが、 現状では定期借家のみでは計湘に必要なサンプル数を十分確保することが困 難であるので本研究では借家データ全体を対象として計測を行った。

6) 高齢者向け貨貸住宅としては、この他にも多様なバリエーションが想定可能 であるが、本稿では「家貨負担力の観点からの検討」という研究の趣旨に照 らし、標鹤的なケースとしてこの仮定を設けている。

7) 東京都住宅局編 : 平成12年度東京都住宅白書〜東京居住の姿をさぐる住宅 政策の新たな展開に向けて, 2000, pp77-91

参考文献

1)古田健一他: 二大都市圈における持家住替えの地区特性一住替えによる住宅 変化および居住地移動に関する研究 その 1 -、日本建築学会計画系論文集、 第495 号、pp181-188、1997年 5 月

2) 長谷川洋他 : 昭和59 63年の間の居住地移動からみた首都图の圈域構造一大 都市圈に扔ける居住地移動に関する研究 その 1 -、日本建築学会計画系論 文集、第493 号、pp215-222、1997年 3月

3) 石坂公一他 : 首都圈における圈内移転市場棈造の時系列変化一大都市圈にお ける居住地移動に関する研究 その 2 -、日本建築学会計画系論文集、第521 号、 $\mathrm{pp} 245-252 、 1999$ 年 7 月

4) 長谷川洋他 : 民営借家の規模別定住率特性一首都圈の中高層・民営借家を中 心として一、日本建築学会計画系論文集、第519 号、pp233-239、1999年 5 月

5)多治見左近 : 居住残留率の推定に関する試論的研究一居住残留率のモデルと 近畿都市圈における検証一、日本建築学会計画系論文集、第 522 号、 $\mathrm{pp} 271$ $277 、 1999$ 年 8 月

6) 璘地吉信他 : 世帯移動に伴う空き家数の変化に関する検討一中古借家市場の 有効性に関する研究（その1）一、日本建築学会計画系論文集、第533 号、 $\mathrm{pp} 151-156 、 2000$ 年 7 月

7) 菊地吉信他 : 都道府県を単位とした民学借家転入率の算定一中古借家市場の 有効性に関する研究（その 2) 一、日本建築学会計画系論文集、第545 号、 pp243-250、2001年 7 月

8)石坂公一他 : 既存住宅ストックの有效活用による居住状况改善の可能性、日 本建築学会計画系論文集、第551 号、pp267-273、2002年 1 月

（2002年12月 9 日原稿受理，2003年 4 月 28 日採用决定） 